\title{
Editorial
}

\section{Does governance make a difference?}

\author{
International Journal of Disclosure and Governance (2011) 8, 1-3. doi:10.1057/jdg.2010.32
}

The crisis in the banking sectors of the United States and Europe, which began in October 2008, continues to have severe repercussions, as demonstrated most recently by the bailout of Ireland, a country brought to its knees by the open-ended guarantee of Irish bank liabilities extended at the height of the crisis. Although some banks have begun to recover their financial health thanks to the low interest rate policies instituted by central banks, little consensus has been reached as to what it would take to prevent a repetition of a similar crisis in the future.

The United States did pass, in July 2010, the Dodd-Frank Wall Street Reform and Consumer Protection Act with its numerous new regulations and reforms, but there is much criticism that it is ineffective - especially with regard to the key issue of dealing with 'too big to fail' banks. ${ }^{1}$ As the New York Times of 26 June 2010 stated 'On the final item, the bill fails completely. After President Obama signs it into law, the nation's financial industry will still be dominated by a handful of institutions that are too large, too interconnected and too politically powerful to be allowed to go bankrupt if they make unwise decisions or make huge wrong-way bets'. Indeed, as Thomas M. Hoenig, the President of the Federal Reserve Bank of Kansas City pointed out recently, the five largest banks in the United States are significantly larger now than they were before the crisis hit, and between them control assets equal to over 60 per cent of US GDP - perhaps not up the stratospheric levels of Ireland's benighted banks, but surely still too big to fail. ${ }^{2}$

To add to the uncertainty, the newly elected Republican majority in the House of
Representatives has promised to repeal the legislation. Incredible as it may seem, even as the baleful effects of the credit crisis continue in the form of high unemployment and unprecedented austerity, the political momentum in the United States is towards less rather than more regulation of the financial sector.

If regulation is off the table, then that leaves better internal governance as the mechanism to prevent a repetition of the problems that resulted in the crisis in the banks. Unfortunately, recent academic study of the impact of governance practices on bank performance before and during the crisis does not lead to a very hopeful conclusion.

Erkens et al (2010) undertook a study of 296 financial firms from 30 countries affected by the credit crisis in the period 2007-2008 to determine whether those banks with better measures of governance beforehand performed better during the crisis. The researchers measured governance by the percentage of the board of directors that were independent, and on the presence of institutional and large shareholders who are presumed to be better placed to play a monitoring and disciplining role with bank management. Unfortunately, the authors found that banks with more independent directors or large shareholders in fact performed worse during the crisis and pessimistically conclude that 'overall, our findings cast doubt on whether regulatory changes that increase shareholder activism and monitoring by outside directors will be effective in reducing the consequences of future economic crises'.

A similarly negative finding on the benefits of governance was reached by Beltratti and Stulz (2009) who examined 98 large banks with assets 
over US $\$ 50$ billion each at the end of 2006, 19 of them being in the United States. The metric for governance used by these authors was the banks' ranking on the Corporate Governance Quotient, which is a corporate governance rating system provided by Institutional Shareholder Services on over 8000 companies worldwide, which evaluates the strengths, deficiencies and risks of a company's corporate governance practices and board of directors. ${ }^{3}$ As with the previous study, these authors found that banks with better measures of corporate governance had worse stock market performance during the crisis, which leads to their conclusion that 'banks with more shareholder friendly boards, which are banks that conventional wisdom would have considered to be better governed, fared worse during the crisis'. Like Erkens et al (2010), Beltratti and Stulz (2009) also find that banks with a greater percentage of independent directors saw their share price fall more during the crisis than their peers with boards that by conventional standards were lacking from a governance point of view.

Interestingly, the reason both sets of researchers posit for their counterintuitive findings is that, at the time, the risky strategies that eventually resulted in the crash, such as heavy investments in subprime mortgages and complex derivative trading, were considered to be good business practice. Only in hindsight was it 'obvious' that such strategies were destined to lead to disaster, and that good governance required directors to step in and stop their banks from doing what all their peers were doing, even if that risked lower returns in the short run. As Chuck Prince, then CEO of Citigroup, stated in July 2007, 'as long as the music is playing, you've got to get up and dance. We're still dancing'. Sounds silly now, but at the time, what was the real alternative?

Another reason for the failure of internal governance practices to safeguard banks was that along with independence of directors came a lack of knowledge, or perhaps even lack of involvement, a problem that is exacerbated by the surprising finding by Beltratti and Stulz (2009) that bank directors are paid relatively less than directors of similarly sized non-financial firms. As they state: 'Banks receiving bailout money had boards that were more independent and bank directors earned significantly less compensation than their counterparts in nonfinancial firms. What this suggests is that board independence may not necessarily be beneficial for banks. Independent directors may not always have the expertise necessary to oversee complex banking firms. The fact that bank directors earn so much less than their counterparties in nonfinancial firms raises the possibility that the pool of bank directors is different from the pool of directors of nonfinancial firms'. In short, independence of directors loses its value when it becomes an end in itself and not a means towards more effective governance. This is a point we have made before in this journal (see Lorne, 2008).

Of course, the fact that superior external measures of governance does not necessarily guarantee good governance, let alone good performance, is not a new insight, and was demonstrated perhaps most vividly by the experience of the Indian software firm Satyam Computer Services, which won the Golden Peacock Global Award for Excellence in Corporate Governance in September 2008. This was the latest in a series of such awards praising the company's good governance practices. The Investor Relations Global Rankings rated Satyam as the company with Best Corporate Governance Practices for 2006 and 2007. It also won the Golden Peacock Award for Excellence in Corporate Governance from the Institute of Directors in New Delhi in 2002. G. Jayaraman, Satyam's Global Head of Corporate Governance stated when accepting its last award that: 'This honor demonstrates the value Satyam places on corporate governance, and on the importance of serving the interests of our investors, clients, associates and of society'.

Alas, as our readers will well recall, just 4 months later, in January 2009, Satyam's Chairman Ramalinga Raju resigned and admitted a decade long fraud that had misstated earnings by over a billion dollars. 
The authors of these papers have provided a valuable lesson on the value added that academic research can provide, testing assumptions taken for granted and overturning conventional wisdom. Providing effective governance of organizations as large, complex and multi-faceted as the modern international bank is not easy or obvious. While one can put forward such broad generalities as having more independent directors or separating the posts of chairman and CEO, the fact is that there are no guarantees that any of these best practices will result in better performance.

But such findings are not necessarily indications that banks cannot benefit from better governance, but rather, that governance of banks needs to be rethought. If, as these studies conclude, existing governance practices are ineffective, then perhaps it is time to develop a new paradigm for bank governance.

That leads to me to subject of the 2011 Special Issue of the journal, which focuses on financial crises and regulatory responses. The call for papers was included in the last issue of the journal and can also be found on the journal website. We are fortunate to have as editors for the special issue two very distinguished and knowledgeable Wall Street insiders, Simon Lorne, Vice Chairman and Chief Legal Officer, Millennium Management and former General Counsel, SEC and Jim Bicksler, Professor of Finance, Rutgers Business School and a new member of the journal's editorial board.

I have every expectation that this year's special issue will be as successful as last year's one on the Audit Profession, which concludes in this issue. I would like to offer special thanks on behalf of our readers to Trevor Stewart and Don Warren who so ably edited that special issue and I trust that our articles this year will maintain the high standard that they have set.

\section{NOTES}

1 http://frwebgate.access.gpo.gov/cgi-bin/getdoc .coi? dbname=111_cong_bills\&docid=f:h4173enr .txt.pdf.

2 New York Times, 1 December 2010.

3 http://www.riskmetrics.com/cgq.

\section{REFERENCES}

Beltratti, A. and Stulz, R.M. (2009) Why Did Some Banks Perform Better during the Credit Crisis? A Cross-Country Study of the Impact of Governance and Regulation. Fisher College of Business Working Paper No. 2009-03-012. Available at SSRN: http://ssrn.com/abstract= 1433502.

Erkens, D., Hung, M. and Matos, P.P. (2010) Corporate Governance in the 2007-2008 Financial Crisis: Evidence from Financial Institutions Worldwide. ECGI - Finance Working Paper No. 249/2009; CELS 2009 4th Annual Conference on Empirical Legal Studies Paper. Available at SSRN: http://ssrn.com/abstract= 1397685.

Lorne, S. (2008) Economics, regulation and governance. International Journal of Disclosure and Governance 5(4): 287-293.

Michael Alles Editor 